Bangladesh J. Bot. 41(1): 55-60, 2012 (June)

\title{
BACTERIOLOGICAL AND PHYSICOCHEMICAL WATER QUALITY OF FOUR PONDS OF DHAKA METROPOLIS
}

\author{
Mihir Lal Saha*, Meherun Nessa, Mahbubar Rahman Khan, \\ MOHAMmad Nurul Islam and Sirajul Hoque ${ }^{1}$ \\ Department of Botany, University of Dhaka, Dhaka-1000, Bangladesh
}

Key words: Bacteria, Pond water, Fecal pollution, Multi drug resistance

\begin{abstract}
The aerobic heterotrophic bacterial count of four pond water samples ranged between $6.92 \times 10^{4}$ and $1.72 \times 10^{6} \mathrm{cfu} / 100 \mathrm{ml}$. The highest count $\left(1.72 \times 10^{6} \mathrm{cfu} / 100 \mathrm{ml}\right)$ was recorded in Zahurul Haq Hall pond water. Enteric bacterial count was found in between $1.69 \times 10^{4}$ and $3.31 \times 10^{5} \mathrm{cfu} / 100 \mathrm{ml}$ in water samples. A total of 79 isolates were obtained of which 24 were randomly selected for further study. Among them Bacillus, Micrococcus and Planococcus were Gram-positive, while Escherichia, Enterobacter and Klebsiella were Gram-negative. Physicochemical parameters of the ponds satisfied water quality standards except $\mathrm{NH}_{4}{ }^{+}-\mathrm{N}$. Among the ponds, $\mathrm{COD}_{\mathrm{Cr}}$ and $\mathrm{BOD}_{5}$ values of the water samples were 18.29-19.75 mg/l and 3.18-6.05 mg/l, respectively. Most of the Gram negative bacteria were found to be multi drug resistant.
\end{abstract}

\section{Introduction}

Water pollution by harmful microorganisms is now a global problem. Pollution can also be caused by a wide variety of inorganic and organic compounds (Higgins and Burns 1975). Municipal waste water is a primary contributor of bacteria to the aquatic environment (Linton et al. 1981). Fecal coliform bacteria are the most commonly used indicators of fecal pollution in water and food. The fecal oral diseases may be transmitted by direct person to person contact, by contaminated food or by contaminated water (Pipes 1982).

Ponds of Azimpur Colony, Jagannath Hall, Shahidullah Hall and Zahurul Haq Hall are being frequently used by the residential students, employees of Dhaka University and floating people for bathing, swimming and many other household chores. Studies on the pollution aspects of this kind of water are very significant because many city dwellers specially the slum ones use this type of water for their domestic purposes (Geldreich 1996). Indicator microorganisms such as total coliforms, fecal coliform and fecal streptococci have been used as models for the potential presence of pathogenic microorganisms in water samples (Patra et al. 2009). The physicochemical features and bacterial flora of Dhanmondi and Gulshan lakes were investigated earlier (Khondker and Parveen 1992, Saha et al. 2002, 2011).

The present work was undertaken to assess bacteriological and physicochemical profile of the selected ponds of Dhaka Metropolis as well as drug resistance pattern of the bacteria associated with the pond water.

\section{Materials and Methods}

Water samples were collected from four selected ponds, namely Azimpur Colony, Jagannath Hall, Shahidullah Hall and Zahurul Haq Hall of Dhaka Metropolis $\left(23^{\circ} 43^{\prime} \mathrm{N}\right.$ and $\left.90^{\circ} 25^{\prime} \mathrm{E}\right)$ in the month of October, 2009. Samples were collected in plastic bottles sterilized with alcohol from a depth of $30 \mathrm{~cm}$ below the surface from four different sites of each pond. Nutrient agar medium was used for the enumeration and isolation of aerobic heterotrophic bacteria. MacConkey agar was

*Author for correspondence: <sahaml@yahoo.com>. ${ }^{1}$ Department of Soil, Water and Environment, University of Dhaka, Dhaka-1000, Bangladesh. 
used for the enteric and related bacteria. The $\mathrm{pH}$ of the culture media was adjusted to 7.2 before sterilization. Three different techniques, namely serial dilution plate (APHA 1998), spread plate (Sharp and Lyles 1969) and membrane filtration technique (Atlas et al. 1995) were used for the enumeration and isolation of bacteria. Plating in duplicate plates was made for each diluted sample. Inoculated plates were incubated at $37^{\circ} \mathrm{C}$ for $24 \mathrm{~h}$.

Bacterial colony forming unit (cfu) was recorded by a digital colony counter (OSK 10086, DC-3, Japan). For provisional identification of the isolates, important biochemical tests such as carbohydrate fermentation, catalase, oxidase, deep glucose agar, V.P., M.R., indole, citrate utilization, egg-yolk lecithinase, starch hydrolysis, casein hydrolysis, protease, gelatin hydrolysis, KIA, nitrate reduction, citrate utilization, oxidase, urease, etc. were carried out. Bergey's Manual for Systematic Bacteriology (Sneath et al. 1986) was followed for the identification of Grampositive bacterial isolates. The enteric bacteria were identified following Manual for Laboratory Investigations of Acute Enteric Infections (WHO 1987) and Bergey's Manual for Systematic Bacteriology (Krieg and Holt 1984).

Temperature of water was measured at the time of sampling with the help of a mercury thermometer. The $\mathrm{pH}$ of collected water samples was measured with electric $\mathrm{pH}$ meter. For chemical analysis, samples were filtered (Whatman No. 42, England) to eliminate suspended solid particles. Nitrite-nitrogen was determined by modified Griess-Ilosvay method (Barnes and Folkard 1951, Bremner 1965) while nitrate-nitrogen was determined colorimetrically (Joergensen and Brookes 1990). To determine ammonium nitrogen, water samples were distilled under alkaline condition in a micro Kjeldahl distillation apparatus (Jackson 1973). Phosphorus content was determined by ascorbic acid blue method (Murphy and Riley 1962). Biological oxygen demand $\left(\mathrm{BOD}_{5}\right)$ was determined by BOD meter (Mettler-Todelo CH-8603 Schwerzenbanch, USA) while chemical oxygen demand $\left(\mathrm{COD}_{\mathrm{Cr}}\right)$ was analysed by the method based on chemical oxidation of materials in the presence of catalyst by $\mathrm{Cr}_{2} \mathrm{O}_{7}{ }^{2-}$ in $50 \% \mathrm{H}_{2} \mathrm{SO}_{4}$ as described by De (1999).

\section{Results and Discussion}

The aerobic heterotrophic bacterial count of the water samples of the four ponds ranged in between $6.92 \times 10^{4}$ and $1.72 \times 10^{6} \mathrm{cfu} / 100 \mathrm{ml}$ (Table 1). The maximum aerobic heterotrophic bacterial count $\left(1.72 \times 10^{6} \mathrm{cfu} / 100 \mathrm{ml}\right)$ was observed in Zahurul Haq Hall pond water samples and the minimum number $\left(6.92 \times 10^{4} \mathrm{cfu} / 100 \mathrm{ml}\right)$ was in Shahidullah Hall. Enteric bacterial count

Table 1. Viable heterotrophic bacterial load of four pond water.

\begin{tabular}{lccc}
\hline $\begin{array}{l}\text { Selected } \\
\text { pond }\end{array}$ & $\begin{array}{c}\text { Heterotrophic bacteria } \\
(\mathrm{cfu} / 100 \mathrm{ml})\end{array}$ & $\begin{array}{c}\text { Enteric bacteria } \\
(\mathrm{cfu} / 100 \mathrm{ml})\end{array}$ & $\begin{array}{c}\text { Total bacteria } \\
(\mathrm{cfu} / 100 \mathrm{ml})\end{array}$ \\
\hline Azimpur Colony & $1.07 \times 10^{6}$ & $3.31 \times 10^{5}$ & $1.40 \times 10^{6}$ \\
Jagannath Hall & $1.79 \times 10^{5}$ & $1.70 \times 10^{4}$ & $1.96 \times 10^{5}$ \\
Zahurul Haq Hall & $1.72 \times 10^{6}$ & $1.20 \times 10^{5}$ & $1.84 \times 10^{6}$ \\
Shahidullah Hall & $6.92 \times 10^{4}$ & $1.69 \times 10^{4}$ & $8.61 \times 10^{4}$ \\
\hline
\end{tabular}

ranged between $1.69 \times 10^{4} \mathrm{cfu} / 100 \mathrm{ml}$ and $3.31 \times 10^{5} \mathrm{cfu} / 100 \mathrm{ml}$. The maximum enteric bacterial count $\left(3.31 \times 10^{5} \mathrm{cfu} / 100 \mathrm{ml}\right)$ was found in the water samples of Azimpur Colony pond and the minimum count $\left(1.69 \times 10^{4} \mathrm{cfu} / 100 \mathrm{ml}\right)$ was found in Shahidullah Hall. The total bacterial loads of the four different ponds were as $1.40 \times 10^{6}, 1.96 \times 10^{5}, 1.84 \times 10^{6}$ and $8.61 \times 10^{4} \mathrm{cfu} / 100 \mathrm{ml}$, respectively. 
Table 2 showed the physicochemical properties of four selected pond water. The water temperature and $\mathrm{pH}$ values ranged from $27.0-28.5^{\circ} \mathrm{C}$ and $7.31-7.47$, respectively. In this investigation, the $\mathrm{BOD}_{5}$ and $\mathrm{COD}_{\mathrm{Cr}}$ values of the water samples ranged between 3.18 and 6.05 and 18.2 and $19.7 \mathrm{mg} / \mathrm{l}$, respectively. According to the United States Public Health standard, 5 and 4 $\mathrm{mg} / \mathrm{l} \mathrm{BOD}$ and COD, respectively indicated the quality for domestic and drinking water (De 1999). Higher $\mathrm{COD}_{\mathrm{Cr}}$ values than $\mathrm{BOD}_{5}$ indicated that water of these ponds were considerably polluted with non-biodegradable chemical pollutants (Table 2). Phosphorus level of water samples was in between 0.0015 and $0.0025 \mathrm{mg} / \mathrm{l}$. Nitrite-nitrogen values ranged between 0.004 and 0.104 $\mathrm{mg} / \mathrm{l}$. Nitrate-nitrogen content of the water samples was found to be insignificant. Natural level of nitrate-nitrogen in ground and surface water is usually below $0.2 \mathrm{mg} / \mathrm{l}$, but toxicological effects are observed only at exposures above $200 \mathrm{mg} / \mathrm{kg}$ of body weight. Naturally occurring nitrate levels in surface and ground water generally a few milligrams per liter. On the other hand extensive epidemiological data support the current guideline values for $\mathrm{NO}_{3}{ }^{-} \mathrm{-N}$ of $10 \mathrm{mg} / \mathrm{l}$ (WHO 1993). In this study, the level of nitrogen $\left(\mathrm{NO}_{3}{ }^{-}-\mathrm{N}\right.$ and $\left.\mathrm{NO}_{2}{ }^{-}-\mathrm{N}\right)$ found lower than the normal level in ground water and surface water. Higher concentrations of $\mathrm{NH}_{4}{ }^{+} \mathrm{N}$ and trace amount of nitrate nitrogen were noticed in all ponds. This could be due to improper nitrification of the aquatic environment. According to the United States Public Health, drinking water standards were $\mathrm{pH} 6.0$ - 8.5, $\mathrm{NH}_{4} 0.5$ $\mathrm{mg} / \mathrm{l}, \mathrm{NO}_{2}<10$ and $\mathrm{NO}_{3}<10$ to $45 \mathrm{mg} / \mathrm{l}$ (De 1999). During the present study, major chemical contents like $\mathrm{NO}_{3}^{-}-\mathrm{N}, \mathrm{NO}_{2}^{-}-\mathrm{N}$ and phosphorus values were found to be within safety level from pollution point of view.

Table 2. Physicochemical properties of four pond water.

\begin{tabular}{lccccccccc}
\hline $\begin{array}{l}\text { Selected } \\
\text { pond }\end{array}$ & $\begin{array}{c}\text { Temp. } \\
\left({ }^{\circ} \mathrm{C}\right)\end{array}$ & $\mathrm{pH}$ & $\begin{array}{c}\mathrm{TSS} \\
(\mathrm{mg} / \mathrm{l})\end{array}$ & $\begin{array}{c}\mathrm{BOD} \\
(\mathrm{mg} / \mathrm{l})\end{array}$ & $\begin{array}{c}\mathrm{COD} \\
(\mathrm{mg} / \mathrm{l})\end{array}$ & $\begin{array}{c}\mathrm{P} \\
(\mathrm{mg} / \mathrm{l})\end{array}$ & $\begin{array}{c}\mathrm{NO}_{2}{ }^{-}-\mathrm{N} \\
(\mathrm{mg} / \mathrm{l})\end{array}$ & $\begin{array}{c}\mathrm{NO}_{3}{ }^{-}-\mathrm{N} \\
(\mathrm{mg} / \mathrm{l})\end{array}$ & $\begin{array}{c}\mathrm{NH}_{4}{ }^{+}-\mathrm{N} \\
(\mathrm{mg} / \mathrm{l})\end{array}$ \\
\hline Azimpur Colony & 28.0 & 7.31 & 0.316 & 3.18 & 19.02 & 0.0025 & 0.104 & Trace & 45.90 \\
Jagannath Hall & 27.5 & 7.40 & 0.318 & 4.22 & 19.75 & 0.0022 & 0.018 & Trace & 97.50 \\
Zahurul Haq Hall & 27.0 & 7.47 & 0.406 & 6.05 & 19.27 & 0.0020 & 0.004 & Trace & 18.74 \\
Shahidullah Hall & 28.5 & 7.44 & 0.120 & 5.71 & 18.29 & 0.0015 & 0.006 & Trace & 48.62 \\
\hline
\end{tabular}

During this investigation, primarily 79 isolates were selected and finally 24 were provisionally identified on the basis of their morphological characters, Gram reaction and biochemical tests (Table 3). Among 24 isolates, 19 were Gram-positive and remaining 5 were Gram-negative. Among the Gram-positive, 17 isolates were rod, spore former and members of the genus Bacillus. The remaining two were the members of Micrococcus and Planococcus. The result clearly indicated that among the Gram-positive bacteria, spore former Bacillus was the dominant genus. Gram-negative bacterial isolates belonged to the genus Sphingomonas, Escherichia, Enterobacter and Klebsiella.

Varatraj and Ayjappan (1989) reported 337 bacterial strains isolated from fresh water bodies of Bangalore and the dominant genera were Bacillus, Pseudomonas, Enterobacter, Aeromonas, Flavobacterium, Corynebacterium and cocci. Bacillus, Salmonella, Escherichia, Enterobacter, Serratia, Alcaligenes, Aeromonas, Proteus and Pseudomonas were the dominating bacteria in Dhanmondi and Gulshan lakes water (Saha et al. 2002, 2011). During this study quite similar result was observed and possible fecal contamination could be mentioned. The coliform group of bacteria in general and E. coli in particular, has found universal application as indicators of fecal contamination (Godfree et al. 1997). Presence of E. coli, in this study indicated possible fecal pollution of these ponds. The pond of Azimpur colony was found to be worse in the context enteric bacterial load. The load of aerobic heterotrophic bacteria and the presence of Enterobacter, 


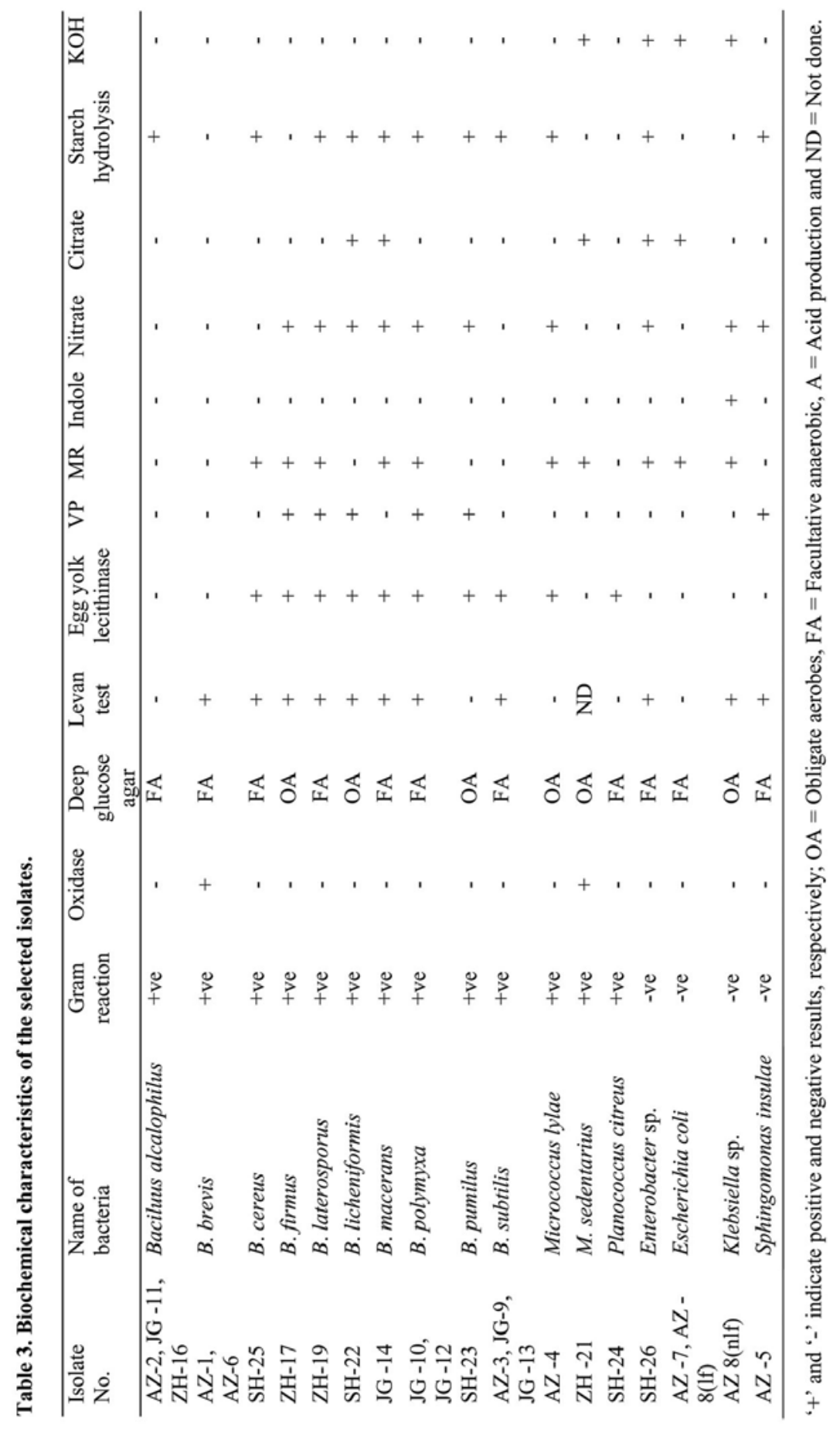


Escherichia, Klebsiella, etc. in the samples clearly showed significant level of microbial pollution of the ponds. In India, Patra et al. (2009) showed positive relationships between fecal indicators and pathogenic microorganisms. A good number of enteric bacteria and the presence of $E$. coli, Enterobacter and Klebsiella in the water sample indicated the fecal pollution of the ponds.

Table 4. Culture and sensitivity test of the selected isolates against different antibiotics.

\begin{tabular}{|c|c|c|c|c|c|c|c|}
\hline \multirow{3}{*}{$\begin{array}{l}\text { Name of } \\
\text { bacteria }\end{array}$} & \multicolumn{7}{|c|}{ Inhibition zone (mm) } \\
\hline & \multicolumn{7}{|c|}{ Antibiotics } \\
\hline & VA 30 & P 10 & RD 5 & CN 120 & N 30 & PB 300 & S 10 \\
\hline Bacillus & $\mathrm{S}$ & $S$ & $S$ & $\mathrm{~S}$ & $S$ & $S$ & $S$ \\
\hline alcalophilus & $(27.0)$ & $(51.0)$ & (34.0) & (34.5) & $(25.5)$ & $(18.5)$ & $(26.0)$ \\
\hline \multirow[t]{2}{*}{ B. brevis } & $\mathrm{S}$ & S & S & $\mathrm{S}$ & S & S & S \\
\hline & $(26.5)$ & $(27.0)$ & $(19.5)$ & (35.5) & $(25.5)$ & $(17.5)$ & $(21.0)$ \\
\hline \multirow[t]{2}{*}{ B. firmus } & $\mathrm{S}$ & $\mathrm{S}$ & $\mathrm{S}$ & $\mathrm{S}$ & $\mathrm{S}$ & $\mathrm{S}$ & $\mathrm{S}$ \\
\hline & $(26.5)$ & $(54.0)$ & $(35.0)$ & $(35.5)$ & $(29.0)$ & (18.5) & $(21.0)$ \\
\hline \multirow[t]{2}{*}{ B. macerans } & $\mathrm{S}$ & $\mathrm{S}$ & $\mathrm{S}$ & S & $\mathrm{S}$ & $\mathrm{S}$ & $\mathrm{S}$ \\
\hline & $(25.0)$ & $(54.0)$ & (34.0) & $(32.5)$ & $(26.5)$ & $(16.5)$ & $(20.5)$ \\
\hline \multirow[t]{2}{*}{ B. polymyxa } & $\mathrm{S}$ & $\mathrm{S}$ & $\mathrm{S}$ & $\mathrm{S}$ & $\mathrm{S}$ & $\mathrm{S}$ & $\mathrm{S}$ \\
\hline & $(24.5)$ & $(24.5)$ & $(24.0)$ & $(35.0)$ & $(24.5)$ & $(16.5)$ & $(17.5)$ \\
\hline \multirow[t]{2}{*}{ B. subtilis } & S & S & S & S & S & S & S \\
\hline & $(24.0)$ & $(50.0)$ & $(32.0)$ & $(32.0)$ & (28.5) & (6.5) & (20.5) \\
\hline \multirow[t]{2}{*}{ Micrococcus lylae } & S & S & S & S & S & S & $\mathrm{S}$ \\
\hline & $(18.5)$ & $(17.5)$ & $(41.0)$ & (21.5) & $(18.0)$ & $(14.0)$ & (18.5) \\
\hline \multirow[t]{2}{*}{ M. sedentarius } & $\mathrm{R}$ & $\mathrm{R}$ & $\mathrm{S}$ & $\mathrm{S}$ & $\mathrm{S}$ & $\mathrm{S}$ & $\mathrm{R}$ \\
\hline & $(00)$ & $(00)$ & $(16.0)$ & $(26.0)$ & $(16.0)$ & (15.5) & $(00)$ \\
\hline \multirow[t]{2}{*}{ Enterobacter sp. } & $\mathrm{R}$ & $\mathrm{R}$ & $\mathrm{R}$ & $\mathrm{S}$ & $\mathrm{S}$ & $\mathrm{S}$ & $\mathrm{S}$ \\
\hline & $(00)$ & $(00)$ & $(00)$ & $(23.0)$ & $(16.0)$ & $(15.0)$ & $(16.0)$ \\
\hline \multirow[t]{2}{*}{ Escherichia coli } & $\mathrm{R}$ & $\mathrm{R}$ & $\mathrm{R}$ & $\mathrm{S}$ & $\mathrm{S}$ & $\mathrm{S}$ & $\mathrm{S}$ \\
\hline & $(00)$ & $(00)$ & $(00)$ & $(27.0)$ & (19.0) & $(16.5)$ & $(18.0)$ \\
\hline \multirow[t]{2}{*}{ Klebsiella sp. } & $\mathrm{R}$ & $\mathrm{R}$ & $\mathrm{R}$ & $\mathrm{S}$ & $\mathrm{S}$ & S & $\mathrm{S}$ \\
\hline & $(00)$ & $(00)$ & $(00)$ & $(24.5)$ & $(13.5)$ & $(16.0)$ & $(15.0)$ \\
\hline Sphingomonas & S & $\mathrm{S}$ & S & $\mathrm{S}$ & S & $\mathrm{R}$ & $\mathrm{S}$ \\
\hline insulae & $(19.0)$ & $(27.5)$ & (24.0) & (38.0) & (26.0) & $(11.0)$ & (16.5) \\
\hline
\end{tabular}

$\mathrm{S}=$ Sensitive, $\mathrm{R}=$ Resistant, ND = Not done, VA 30 = Vancomycin, P10 = Penicillin G, RD 5 = Rifampicin, CN120 = Gentamycin, N30 = Neomycin, PB300 = Polymixin B and S10 = Streptomycin.

The bacteria which were isolated from the ponds showed resistance against some common antibiotics (Table 4). Escherichia coli, Klebsiella and Enterobacter were found to be resistant against three common antibiotics viz. vancomycin, penicillin and rifampicin. This multi drug resistance might have arisen due to misuse of antibiotics or prolonged use of single antibiotic. The result suggested that immediate precautions should be taken by the government to stop the selling of antibiotics without prescription, increase the public health concern and ensure the proper use of antibiotics by doctors and patient, respectively. A good number of aerobic heterotrophic bacteria were found in the pond water samples. Presence of enteric bacteria might indicate fecal pollution. Ingestion of these enteric bacteria during bathing and swimming in the ponds might cause intestinal diseases and somehow or rather entrance of waterborne pathogens in food chain around this area. Isolated bacteria were found to be multi drug resistant which is very much alarming. 


\section{Acknowledgement}

Financial support of the Biotechnology Research Centre, University of Dhaka is gratefully acknowledged.

\section{References}

APHA 1998. Standard Methods for the Examination of Water and Wastewater. American Public Health Association, Washington, DC. 1325. pp.

Atlas RM, AE Brown and LC Parks 1995. Laboratory Manual of Experimental Microbiology. Mosbyyearbook, Inc. St. Louis. Missouri. 565. pp

Bremner JM 1965. Nitrogen availability indexes. Agronomy. 9:1324-45.

Barnes H and AR Folkard 1951. The determination of nitrites. Analyst (London). 76: 599-603.

De AK 1999. Environmental Chemistry ( $4^{\text {th }}$ edn.). New Age International Limited Publishers, New Delhi. 364. pp

Geldreich EE 1996. Pathogenic agents in fresh water resources. Hydrological Processes. 10: 315-333.

Godfree AF, D Kay and MD Wyer 1997. Faecal streptococci as indicators of faecal contamination in water. J. Appl. Micribiol. Symp. Supplement. 83: 110-119.

Higgins IJ and RG Burns 1975. The Chemistry and Microbiology of Pollution. Academic Press, London. 256 pp.

Jackson ML 1973. Soil Chemical Analysis. Prentice-Hall, India Private Ltd. New Delhi. 183-200 pp.

Joergensen RG and PC Brookes 1990. Ninhydrin reactive nitrogen measurements of microbial biomass in 0.5 $\mathrm{M} \mathrm{K}_{2} \mathrm{SO}_{4}$ soil extracts. Soil Biology and Biochemistry. 22: 1023-1027.

Khondker M and L Parveen 1992. Study on the physico-chemical limnology of a shallow, hypertrophic artificial lake. Bangladesh.J. Sci. Res. 10(1): 9-16.

Krieg NR and JG Holt (Eds.) 1984. Bergey's Manual of Systematic Bacteriology (9 $9^{\text {th }}$ edn.Vol.1). The Williams and Wilkins Company, Baltimore, U.S.A. 964. pp

Linton AH, JF Timoney and M Hinton 1981. The ecology of chloramphenicol-resistance in Salmonella typhimurium and Escherichia coli in calves with endemic Salmonella infection. J. Appl. Bacteriol. 50: 115-129.

Murphy J and JP Riley 1962. A modified single solution method for determination of phosphate in natural water. Anal. Chem. Acta. 27: 31-36.

Patra AK, BC Acharya and A Mohapatra 2009. Occurrence and distribution of bacterial indicators and pathogens in coastal waters of Orissa. Indian J. Mar. Sc. 38 (4): 474-480

Pipes WO (Ed.) 1982. Bacterial indicators of pollution. CRC Press, Inc. Boca Ration, Florida, USA. 174 pp.

Saha ML, T Bari, MR Khan and S Hoque 2011. Bacteriological and physico-chemical properties of the Gulshan lake, Dhaka. Bangladesh J. Bot. 40(2): 105-111.

Saha ML, MR Khan, R Rahman and S Hoque 2002. Pollution level and bacterial flora of the re-excavated Dhanmondi lake, Dhaka, Bangladesh. Bangladesh J. Bot. 31(1): 9-13.

Sharp MS and ST Lyles 1969. Laboratory Instruction in Biology of Microorganisms. Saint Louis the C V Mosley Company. 23-25. pp.

Sneath PHA, NS Mair, ME Sharpe and JG Holt (Eds.) 1986. Bergey’s Manual of Systematic Bacteriology ( $9^{\text {th }}$ edn. Vol. 2). The Williams and Wilkins Co., Baltimore, USA. 1599.

Varatraj P and S Ayjappan 1989. Population and distribution of heterotrophic bacterial flora in freshwater bodies of Bangalore (India). Indian J. Environ. Health. 31(2): 162-170.

WHO 1987. Manual for Laboratory Investigations of Acute Enteric Infections. WHO/CDD/83.3 Rev. 1, Geneva. 113. pp.

WHO 1993. Guidelines for Drinking Water Quality. (2 ${ }^{\text {nd }}$ edn.) Geneva. 1: 25-100.

(Manuscript received on 10 January, 2012; revised on 17 May, 2012) 